\title{
Landscape level assessment of critically endangered vegetation of Lakshadweep islands using geo-spatial techniques
}

\author{
C Sudhakar Reddy*, Bijan Debnath, P Hari Krishna and C S Jha \\ Forestry $\mathcal{E}$ Ecology Group, National Remote Sensing Centre, Indian Space Research Organisation, \\ Balanagar, Hyderabad 500 625, India. \\ ${ }^{*}$ Corresponding author. e-mail: drsudhakarreddy@gmail.com
}

\begin{abstract}
The conservation of biodiversity is essential for human survival and quality of the environment. Lakshadweep islands are vulnerable to global change and the representing remnant natural vegetation. Landscape fragmentation, disturbance regimes and biological richness have been studied using geo-spatial techniques. Littoral vegetation is the only natural vegetation type of Lakshadweep islands. Altogether 59 patches of the littoral vegetation occupying an area of 137.2 ha were identified. $58.06 \%$ of the littoral vegetation patches belongs to the patch-size class of $<5$ ha. The remnant natural vegetation surviving with patches of less than 20 ha size indicates severe anthropogenic pressure. The fragmentation of littoral vegetation habitat into smaller isolated patches poses one of the key threats to biodiversity and coastal environment. Phytosociological observations revealed distinct plant communities and presence of invasive species in littoral vegetation. The high disturbance areas accounted for $59.11 \%$ area of the total vegetation. The overall spatial distribution of biological richness (BR) in Lakshadweep shows maximum BR at low level (78\%), followed by medium (19\%), high (2\%) and very high (1\%). The study emphasises the importance of conserving the remnant natural vegetation, which is critically endangered.
\end{abstract}

\section{Introduction}

Conservation of natural resources has been the main concern throughout the world, especially since the later part of the 20th century. Vegetation is very important natural resource which provides basis of life. Land use and land cover refers to the physical characteristics of earth's surface, captured in the distribution of vegetation, water, soil and other physical features of the land, including those created solely by human activities (Louisa and Antonio 2001). Changes in land use and land cover have affected bioresource availability and biodiversity at genetic, species and ecosystem levels (Ramachandra et al. 2004). The conventional species level approach has limitations in understanding the priorities of biological conservation, and management has resulted in policy shift from conservation of single species to their habitats (Kempf 1993). Geoinformatics through remote sensing and geographic information system (GIS) provide efficient methods in integrating the spatial information and non-spatial information, which can be effectively used in identification of areas for conservation priority. Remote sensing is an efficient tool for looking at the ecosystem diversity to determine landscape-scale elements of forest biodiversity, such as the relative proportion of matrix and

Keywords. Landscape; fragmentation; disturbance index; biological richness; Lakshadweep; India; landscape; vegetation; geo-spatial. 
patches and their physical arrangement (Innes and Koch 1998). It also brings out disturbance patterns in time and space, which are manifested in the spatial extent and distribution of the vegetation cover as well as species composition.

Mapping the distribution of vegetation types and land use/land cover provides significant information for managing landscapes to maintain their biodiversity. The landscape consists of patches of different land covers. Patch characterization is the best method to analyse patch size, shape and arrangement. The patches are the representation of past and present environmental conditions and human dimensions. Forest fragmentation has been attributed as the major cause of biodiversity loss (Forman and Godron 1986; Jha et al. 2005; Behera and Roy 2010). Through fragmentation, edge effects extend into interior forest areas and is thought to extend no further than $1 \mathrm{~km}$, and some may extend as far as 5-10 km into intact forest areas (Murcia 1995; Curran et al. 1999). The review of literature pertaining to the studies documenting 146 edge effects found that disturbances penetrated to an average distance of $100 \mathrm{~m}$ from forest edge to interior (Broadbent et al. 2008). Properties of landscape such as patch size, the length of edge and the connectedness of habitat patches have a direct influence on the distribution of biodiversity (Ludeke et al. 1990). Fragmentation of ecological units have been well documented at landscape level using patch size, shape, abundance and forest matrix characteristics (Forman and Godron 1986; Lehmkuhl and Ruggiero 1991; Bierregaard et al. 1992). In India, only limited studies have attempted to establish the relationship between the disturbance and the biodiversity of the landscape (Ramesh et al. 1997; Roy et al. 1999).

The present study has been carried out as part of national-level project of biodiversity characterization at landscape level using remote sensing and geographic information system (Reddy 2010).

Lakshadweep islands of India have assumed greater importance in view of the shrinkage and degradation of natural vegetation cover (Reddy and Roy 2011). Currently, the natural vegetation cover of Lakshadweep islands has been estimated to be less than $5 \mathrm{~km}^{2}$ of area and can be included under critically endangered status (Rodriguez et al. 2010; Reddy and Roy 2011). The present study hypothesizes to identify biodiversity conservation priority sites at landscape level interlaced with disturbance index and habitats in Lakshadweep islands using geo-spatial techniques. Remote sensing data have been used primarily to stratify vegetation types, land use and their association. GIS has been used to spatially model the disturbance regimes and biological richness and to integrate the ground-based non-spatial data with the spatial characters of the landscape.

\section{Study area}

Lakshadweep, the smallest Union Territory of India, is an archipelago in the Arabian Sea between latitude $8^{\circ}$ and $12^{\circ} 30^{\prime} \mathrm{N}$ and between longitude $71^{\circ}$ and $74^{\circ} \mathrm{E}$. There are in all 27 islands, 3 reefs and 6 submerged sandbanks (figure 1). The total geographical area of the union territory is $32 \mathrm{~km}^{2}$. Although the land area is extremely small, Lakshadweep islands are bestowed with a large lagoon area of $4200 \mathrm{~km}^{2}$, which is the basis of the physical existence of islands. The land is almost plain with a rise of about 1-6 $\mathrm{m}$ above sea level. 10 islands are inhabited (Agatti, Amini, Androth, Bitra, Chetlat, Kadmat, Kalpeni, Kavaratti, Kiltan and Minicoy) and Bangaram island has a tourist resort only. Lakshadweep islands are vulnerable for global change due to biotic factors, tiny nature, very low elevation (0.1-6 m above msl), climate change and invasive species (Reddy and Roy 2011).

Since these islands are located within the tropics and extend to the equatorial belt, they have a

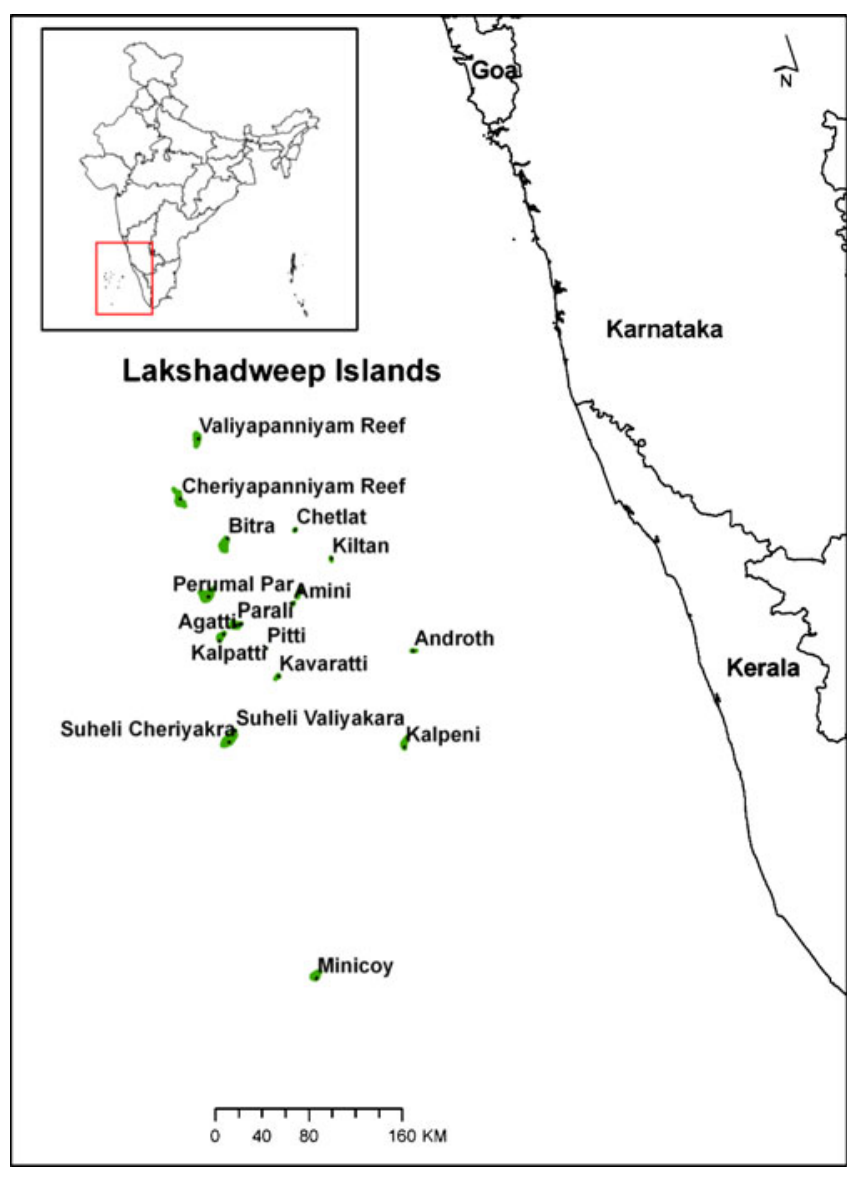

Figure 1. Location map of Lakshadweep islands in India. 
tropical humid, warm and pleasant climate. Temperature varies from $28^{\circ}$ to $32^{\circ} \mathrm{C}$ and relative humidity of $70-80 \%$. The south-west monsoon is the rainy season, which extends from June to October with 80-90 rainy days a year. The average rainfall is $1640 \mathrm{~mm}$ per year. The projected population of the Lakshadweep is 64,429 (Census of India 2011). The livestock population as per census 2003 is 52,000, which has nearly tripled since 1992. About 1680 species of birds, reptiles, fish, crustaceans and corals have been reported from this archipelago (Anonymous 1991). Flora of Lakshadweep represents 348 species of higher plants (Reddy and Roy 2011). The coconut is the only commercial crop and cultivated in majority of islands.

The natural vegetation of the Lakshadweep belong to littoral vegetation type (Champion and Seth 1968). Being situated in the tropics surrounded by sea with flat coral sand, vegetation of Lakshadweep islands shows little variation. The original vegetation in the core sector of inhabited islands is completely replaced by plantations. Irrational methods of raising plantations and habitation are the main cause of destruction of natural vegetation.

\section{Materials and methods}

\subsection{Ground data}

Field studies were carried out during March to April 2010, to cover overall spectrum of vegetation and also to account species diversity. Ground truth data has been used to develop the interpretation criteria for stratifying land cover types. A total of 50 sample points (each 0.04 ha) were laid down with sampling intensity of $0.1 \%$ with reference to the total vegetation area of Lakshadweep. Sample points were allocated based on stratified random sampling method, a tool available in ERDAS Imagine. Phytosociological data, viz., relative frequency, relative density and relative dominance, have been used to compute the importance value index (IVI) for each vegetation strata. IVI has been utilized to calculate species diversity using Shannon-Wiener index (Cottam and Curtis 1956).

\subsection{Remote sensing data}

High-resolution IRS P6 LISS IV data $(5.8 \mathrm{~m}$ spatial resolution) of 2008 was used in the study. The entire Union Territory of Lakshadweep islands have been covered in 12 scenes of IRS P6 LISS IV. The orthorectified Landsat ETM+ data downloaded from GLCF website (http://glcf. umiacs.umd.edu/) was used as reference for georectification using ERDAS IMAGINE 9.2. The extracted false colour composite (FCC) images of selected islands have been shown in figure 2 . The LISS-IV satellite data has been visually interpreted to prepare vegetation and land use map on 1:25,000 scale. The different vegetation cover type (littoral vegetation, plantations) and other land use/land cover categories (settlements and barren lands) were delineated on the basis of tone, texture, association, pattern and variability in spectral reflectance. Accuracy assessment has been carried to evaluate the overall classification accuracy.

\subsection{Landscape analysis}

Landscape metrics have been computed using customized fragstats software (McGarigal et al. 2012). Spatial landscape analysis model (SPLAM), a geospatial modelling software developed for the analysis of porosity, interspersion, fragmentation, juxtaposition, terrain complexity, disturbance index and biological richness, was also used in the landscape analysis (Roy et al. 1999). SPLAM uses a generic binary image as the input and the output is also written in the same format. It has the flexibility to use a variable grid size. The grid size of $24 \times 24 \mathrm{~m}$ has been used for landscape analyses in the present study. The various landscape parameters used for the analysis are: fragmentation, porosity, interspersion and juxtaposition. Fragmentation is number of patches of forest and non-forest in per unit area. It reduces the size and quality of habitat. Porosity is the measure of the number of patches or density of patches within a particular type. It provides an overall clue to the degree of species isolation present and to the potential genetic variability present within flora and fauna population in a landscape. Interspersion is the measure of spatial intermixing of habitats/land cover and is calculated in a non-species-specific manner. It is calculated as the number of surrounding grid cells that differ from the central cell. It represents the heterogeneity or homogeneity of the landscape and hence represents landscape diversity. Juxtaposition is the proximity of the patches determines the intensity of disturbance. Hence, the proximity of natural vegetation and plantation types have been evaluated through juxtaposition. Juxtaposition of the central grid is calculated by comparing the class of the central cell with an adjacent cell as per the weighted preferences of the species and biodiversity values of the vegetation type.

\subsection{Disturbance index (DI)}

The disturbance index has been computed by linearly combining fragmentation, porosity, interspersion, juxtaposition and proximity of road and 


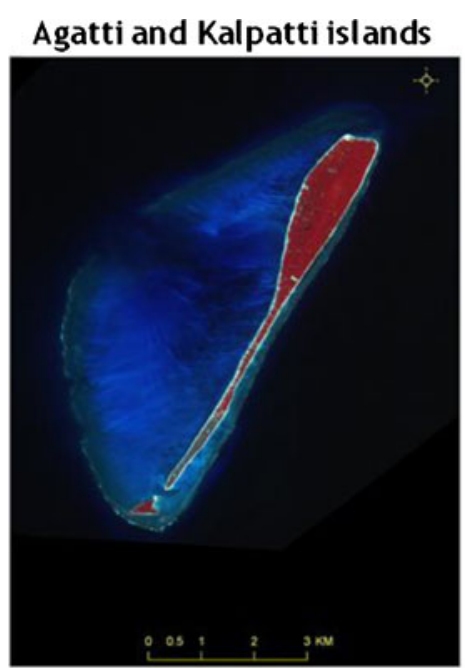

Kavaratti island

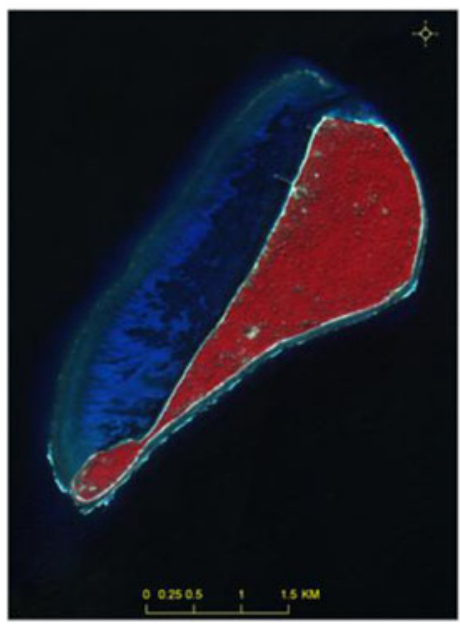

Amini and Kadmat islands

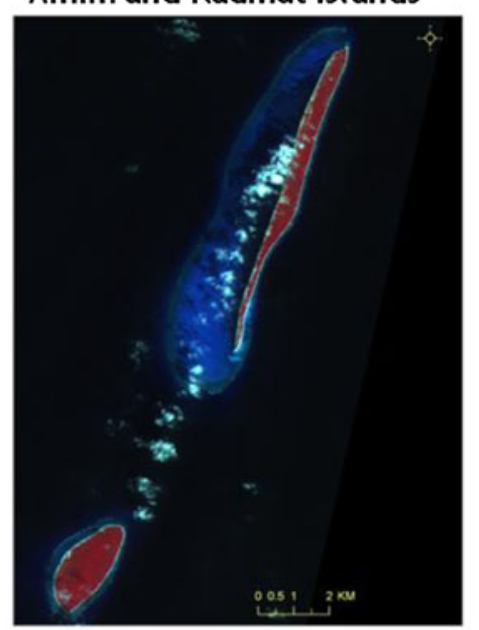

Minicoy island

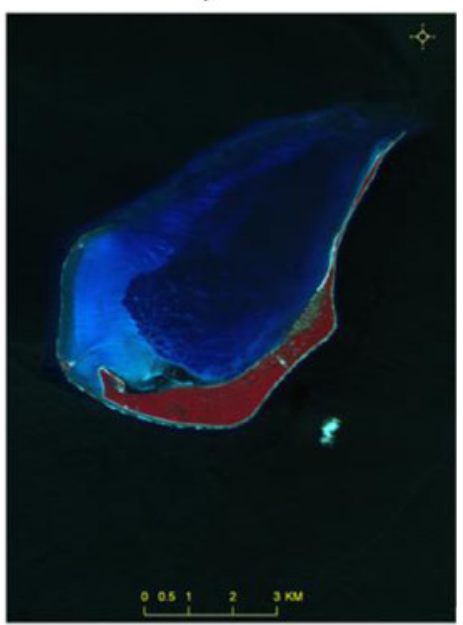

Figure 2. IRS P6 LISS IV false colour composite image of major islands of Lakshadweep.

settlements (Roy et al. 1999). Proximity analysis has been performed to correlate the spatial interrelationship in a horizontal plane. This relationship has been obtained from the analysis of buffer operations. Buffers have been generated for roads as well as habitation locations of the study area at an interval of $50 \mathrm{~m}$. For disturbance index analysis, negative weights have been assigned to the buffers in the proximity of habitation assuming increased disturbance. The spatial representation of disturbance has been calculated by combining landscape elements and disturbance sources as per the following expressions:

$$
\begin{aligned}
\mathrm{DI}=\int\{\text { fragmentation, porosity } \\
\\
\text { interspersion proximity from } \\
\\
\text { disturbance sources } \\
\\
\text { (settlements }+ \text { roads }) \\
\quad \& \text { juxtaposition }\}
\end{aligned}
$$

$$
\begin{aligned}
\text { i.e., } \mathrm{DI}= & \mathrm{W} 1 \mathrm{i} * \mathrm{~F}+\sum_{j}^{k}(\mathrm{~W} 2 \mathrm{i} * \mathrm{Pj}) \\
& +\mathrm{W} 3 \mathrm{i} * \mathrm{I}+\mathrm{W} 4 \mathrm{i} * \mathrm{~B}+\mathrm{W} 5 \mathrm{i} * \mathrm{~J}
\end{aligned}
$$

where Wsi $(\mathrm{s}=1,5)$ are the adaptive probabilistic weightages and $\mathrm{Pj}(\mathrm{j}=1, \mathrm{k})$ are the derived porosity values.

\subsection{Biological richness}

The biological richness map is generated from a combination of outputs of the different sub-models in an iterative process calculated cell by cell across the spatial domain of the model extent. The spatial layers involved in preparation of biological rich areas are disturbance and the non-spatial layers are ecosystem uniqueness, species richness and biodiversity value. The gradients of disturbance identified are weighted with ecosystem uniqueness, species diversity and biodiversity value to identify biologically rich areas (Roy et al. 1999). 


\section{Results}

\subsection{Phytosociological analysis}

The phytosociological data was analysed for understanding the species composition and their characteristics. The widespread occurrence of Scaevola taccada is the characteristic feature of littoral vegetation with IVI of 59.22, followed by Morinda citrifolia, Thespesia populnea, Calophyllum inophyllum, Suriana maritima, Guettarda speciosa and Erythrina variegata with IVI of 42.07, 34.66, $34.26,22.70,19.53$ and 15.02, respectively (table 1). The top 10 tree species represent $93.75 \%$ of individuals. The population of Scaevola taccada represents $28.57 \%$ of total littoral tree species. Littoral vegetation of Agatti, Kavaratti, Bangaram and Thinnakara represents distinct plant communities. Morinda-Calophyllum-Thespesia community is found in Agatti island, Morinda-PandanusSuriana in Kavaratti island, Scaevola-Suriana community in Bangaram island and ScaevolaGuettarda-Premna community in Thinnakara island. The dominance of native coastal elements in top order showed Lakshadweep littoral forests as a climax vegetation type.

In terms of ecological dominance within plantations, the high importance value species is Cocos nucifera (coconut) with IVI of 229.63, followed by Thespesia populnea, Casuarina equisetifolia, Scaevola taccada, Tournefortia argentea and Ochrosia oppositifolia. The overall density of coconut trees is estimated as $88 \%$ in plantations. Tree density per ha is accounted as 310 and 200 in plantations and littoral vegetation, respectively. While mean basal area in plantations and littoral vegetation is 14.64 and $1.41 \mathrm{~m}^{2}$ per ha, respectively. Maximum species diversity is observed in littoral vegetation type based on the Shannon-Wiener index (H') as 3.56. The plantations show values H' as 1.65. Among the shrubs of littoral vegetation, Calotropis gigantea is dominant followed by Clerodendrum inerme, Dodonaea viscosa, Cassia occidentalis and Datura metel. Of the climbers Cassytha filiformis is common followed by Ipomoea alba, Passiflora foetida, Teramnus labialis, Tinospora cordifolia and Tylophora indica. The herbaceous vegetation cover was dominated by Spinifex littoreus, Ipomoea pes-capre, Eragrostis ciliaris, Launaea sarmentosa, Thuarea involuta and Synedrella nodiflora. Among the herbs, Synedrella nodiflora, an invasive alien species occupying $7.78 \%$ of total population is noteworthy. The strand coral vegetation consists of three aquatic angiosperms represented by Thalassia hemprichii, Syringodium isoetifolium and Cymodocea isoetifolia.

\subsection{Vegetation and land use}

The vegetation type map clearly showed that nearly $89.05 \%$ of the geographical area is under vegetation cover (including plantations). The littoral vegetation covers an area of 137.2 ha and proportionately occupies $4.29 \%$ of geographical area (figure 3 ). The majority of land use belongs to plantations and accounted as 2712.3 ha $(84.76 \%)$ of area. Among the non-vegetated area 277.6 ha $(8.68 \%)$ is under barren land (sand). Settlements (built-up area) constitute about 72.9 ha $(2.28 \%$ ) of area. Overall mapping accuracy was computed as $93 \%$.

\subsection{Landscape analysis}

The patch size, fragmentation, shape of the fragments, inter-fragment distances, effect of edge width and disturbance regimes were examined in GIS domain. Patch-size-wise distribution of littoral vegetation presents interesting results. There are 59 patches represented in littoral vegetation and occupying an area of 137.2 ha. Agatti island

Table 1. Top 10 dominant species in each vegetation type in Lakshadweep.

\begin{tabular}{|c|c|c|c|c|c|}
\hline \multicolumn{3}{|c|}{ Littoral vegetation } & \multicolumn{3}{|c|}{ Plantations } \\
\hline Sl. no. & Species & IVI & Sl. no. & Species & IVI \\
\hline 1 & Scaevola taccada & 59.22 & 1 & Cocos nucifera & 229.63 \\
\hline 2 & Morinda citrifolia & 42.07 & 2 & Thespesia populnea & 16.47 \\
\hline 3 & Thespesia populnea & 34.66 & 3 & Casuarina equisetifolia & 11.19 \\
\hline 4 & Calophyllum inophyllum & 34.26 & 4 & Scaevola taccada & 8.18 \\
\hline 5 & Suriana maritima & 22.70 & 5 & Tournefortia argentea & 4.00 \\
\hline 6 & Guettarda speciosa & 19.63 & 6 & Ochrosia oppositifolia & 3.65 \\
\hline 7 & Erythrina variegata & 15.02 & 7 & Azadirachta indica & 3.45 \\
\hline 8 & Premna serratifolia & 14.75 & 8 & Morinda citrifolia & 3.41 \\
\hline 9 & Pandanus odoratissimus & 12.36 & 9 & Cordia subcordata & 1.94 \\
\hline 10 & Tournefortia argentea & 12.13 & 10 & Annona squamosa & 1.87 \\
\hline
\end{tabular}



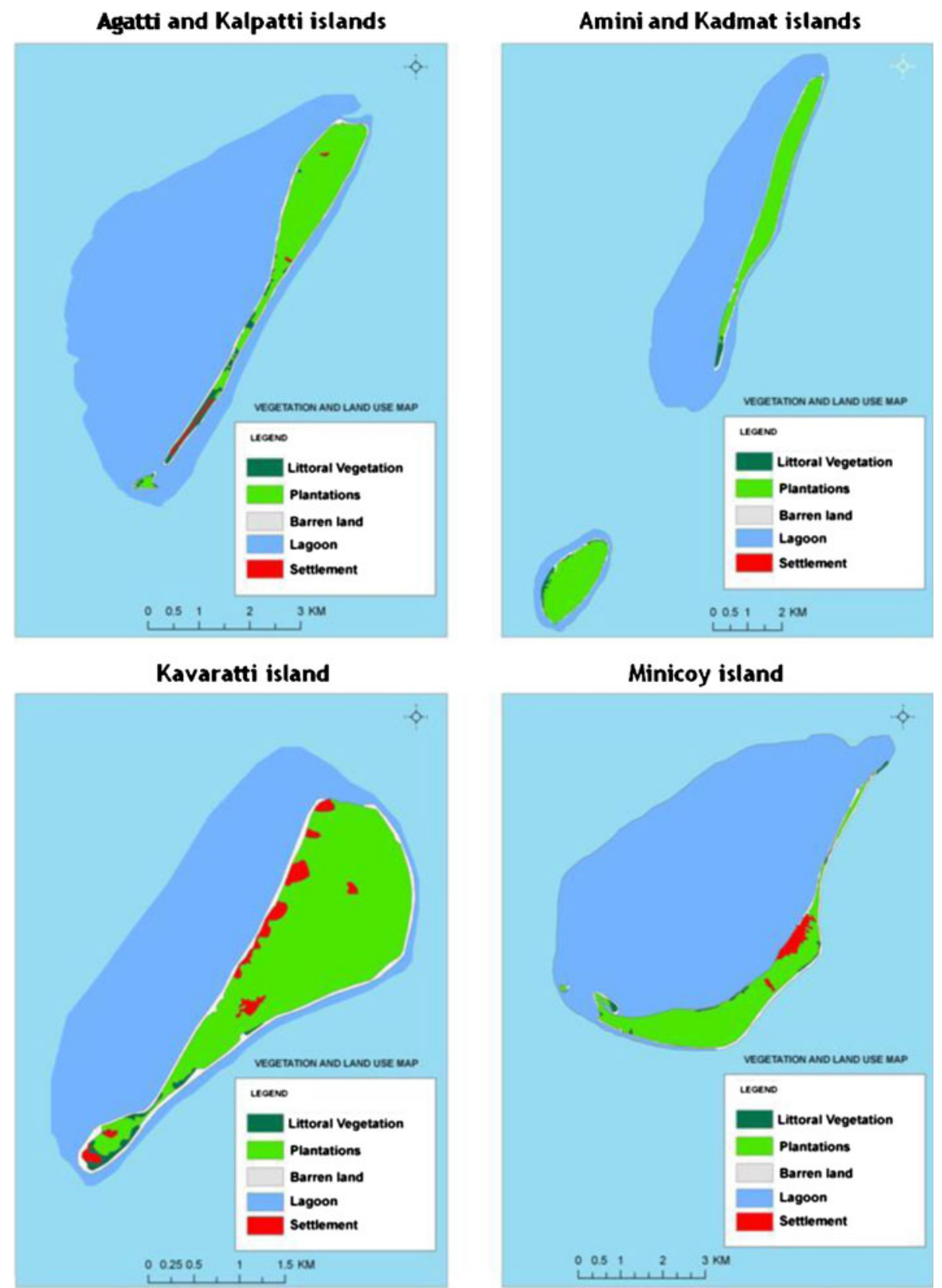

Figure 3. Vegetation and land use map of major islands of Lakshadweep.

represents the largest patch of littoral vegetation of 16.1 ha, followed by Amini island (10.9 ha), Kadmat island (10 ha), Thinnakara island (5.2 ha), Kiltan island (5.2 ha), Kavaratti island (5.1 ha) and Bangaram island (5.0 ha). Patch size of $<5$ ha represents very high number of littoral vegetation patches and proportionately occupy $58.06 \%$ of area (table 2).

The analyses show that the fragments are relatively small and far from each other. About 88.1\% of the littoral vegetation fragments are $<5$ ha, while only about $11.9 \%$ are 5-20 ha. Vegetation fragments are located $200 \mathrm{~m}$ or more apart from each other. At a $300 \mathrm{~m}$ inter-fragment distance, $92.17 \%$ of the littoral vegetation area was included
Table 2. Size class distribution of patches of littoral vegetation of Lakshadweep.

\begin{tabular}{llccl}
\hline $\begin{array}{l}\text { Sl. } \\
\text { no. }\end{array}$ & $\begin{array}{c}\text { Patch } \\
\text { size }\end{array}$ & $\begin{array}{c}\text { No. of } \\
\text { patches }\end{array}$ & $\begin{array}{c}\text { Total area } \\
\text { (ha) }\end{array}$ & $\begin{array}{c}\% \text { of } \\
\text { area }\end{array}$ \\
\hline 1 & $<5$ ha & 52 & 79.7 & 58.06 \\
2 & $5-10$ ha & 4 & 20.5 & 14.91 \\
3 & $10-15$ ha & 2 & 21.0 & 15.27 \\
4 & $15-20$ ha & 1 & 16.1 & 11.76 \\
& Grand total & 59 & 137.2 & 100 \\
\hline
\end{tabular}

in groups of fragments. Patches of equal area may also vary significantly in the amount of their area exposed to edges. GIS analysis shows that 56 
patches of littoral vegetation had elongated linear shapes. Due to the small size and irregular shape of the fragments, the total area of edge zone exceeds that of the interior habitat when the edge width is $50 \mathrm{~m}$. Buffer analysis of $50 \mathrm{~m}(50 \mathrm{~m}$ edge width) inside the polygons of littoral vegetation shows only three intact patches. These patches are distributed in Agatti, Thinnakara and Kadmat islands. At an edge width of $50 \mathrm{~m}$, about $94 \%$ of the total remnant vegetation area is under edge zone. There is no core natural vegetation habitat with a mean distance of $100 \mathrm{~m}$ in Lakshadweep islands.

The results of landscape metrics across different fragmentation indices were shown in table 3 .

Presently the landscape of Lakshadweep was mostly dominated by a fragmented littoral vegetation cover. The largest patch index was $11.73 \%$, which indicates that there are only a few large forest fragments and many very small ones scattered across the landscape. The general trend was towards an increase in the number of fragments and isolation of patches, and a decline in the mean patch size. The mean patch size, patch density, total edge density, mean patch edge and perimeterto-area ratio clearly depict the forest loss and severe fragmentation in the islands. Fractal dimension index of 2.3 indicates intense anthropogenic pressures limiting the narural growth of vegetation in Lakshadweep.

Fragmentation analysis was carried out on $24 \times$ $24 \mathrm{~m}$ cell size of areas on the ground in terms of low to high fragmentation areas on a qualitative basis. The fragmentation analysis statistics of forest type was analysed and categorized into high $(\mathrm{H})$, medium $(\mathrm{M})$ and low $(\mathrm{L})$ areas. The littoral vegetation areas are the moderately fragmented with $48.97 \%$ in the medium fragmentation category followed by $38.11 \%$ of area under

Table 3. Landscape metrics for littoral vegetation of Lakshadweep.

\begin{tabular}{lcr}
\hline \multicolumn{2}{c}{ Sl. no. } \\
\hline I & Patch density and size metrics \\
1 & No. of patches & 59 \\
2 & Mean patch size (ha) & 2.33 \\
3 & Patch density /100 ha & 0.04 \\
II & Edge metrics & \\
4 & Edge density & 87.74 \\
5 & Mean patch edge(m) & 2012.43 \\
III & Shape metrics & 0.03 \\
6 & Perimeter to area ratio & 4.17 \\
7 & Normalised landscape shape index & 11.73 \\
8 & Largest patch index (\%) at class level & 2.3 \\
9 & Fractal dimension index & \\
\hline
\end{tabular}

low fragmentation and $12.92 \%$ under high fragmentation. Plantations are mostly contiguous and $86.22 \%$ of area belongs to low fragmentation category.

The disturbance index map is generated by integration of various landscape parameters of human disturbance, porosity, patchiness, juxtaposition and interspersion. All these parameters excepting human disturbance are derived through GIS analysis of vegetation type map. The disturbance index map is also represented in the three qualitative levels. The disturbance map has been qualitatively categorized into high, medium and low areas (figure 4). The area statistics under various vegetation types have shown high disturbance $(59.11 \%)$ followed by $31.70 \%$ in the medium category and $9.19 \%$ in the low category. This indicates that the remnant natural vegetation in Lakshadweep islands are undergoing intense anthropogenic pressure.

The BR map is a product of disturbance index, terrain complexity, ecosystem uniqueness, species richness and biological value. The last three parameters are derived from the ground phytosociological analysis. The biological richness map is divided in low, medium, high and very high categories. The overall distribution of BR in Lakshadweep shows maximum BR at low level (78\%), followed by medium (19\%), high (2\%) and very high (1\%) (figure 5). The very high biodiversity zones have been found in Thinnakara, Agatti and Kadmat islands. The very high biological richness in these regions is a result of favourable edaphic conditions, regrowth of vegetation and conservation measures taken in the region. High biodiversity zones are found in some parts of Kavaratti and Minicoy islands and uninhabited islands. The species composition of high biodiversity areas represents several tree species (Cordia subcordata, Erythrina variegata, Euphorbia tirucalli, Guettarda speciosa, Morinda citrifolia, Ochrosia oppositifolia, Pandanus odoratissimus, Pemphis acidula, Premna serratifolia, Scaevola taccada, Suriana maritima, Terminalia catappa, Thespesia populnea, Tournefortia argentea), shrubs (Abutilon indicum, Calotropis gigantea, Cassia occidentalis, Clerodendrum inerme, Datura metel, Dodonaea viscosa, Jatropha curcas, Lantana camara, Leea indica, Murraya koenigii), herbs (Acalypha indica, Aerva lanata, Allmonia nodiflora, Alysicarpus vaginalis, Argemone mexicana, Bidens pilosa, Boerhavia diffusa, Cassia tora, Cleome rutidosperma, Cleome viscosa, Colocasia esculenta, Commelina diffusa, Corchorus aestuans, Crotalaria pallida, Cynodon dactylon, Digera muricata, Emilia sonchifolia, Eragrostis ciliaris, Euphorbia hirta, Evolvulus alsinoides, Fimbristylis cymosa, Fimbristylis miliacea, Hedyotis corymbosa, Hedyotis puberula, Ipomoea pes-capre, Launaea 
Agatti and Kalpatti islands

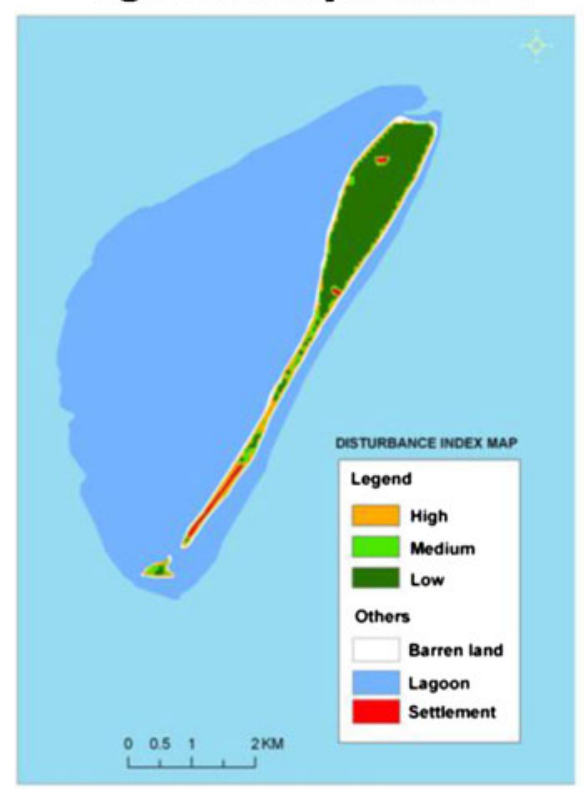

Kavaratti island

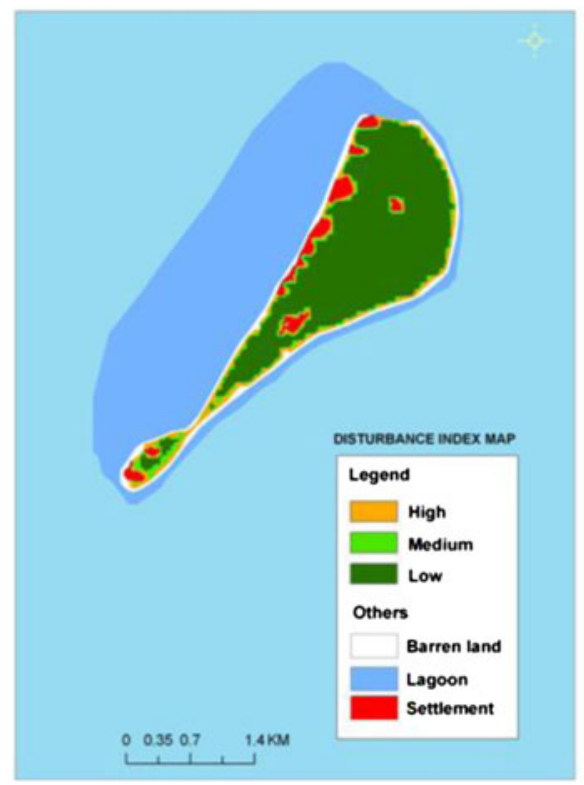

Amini and Kadmat islands

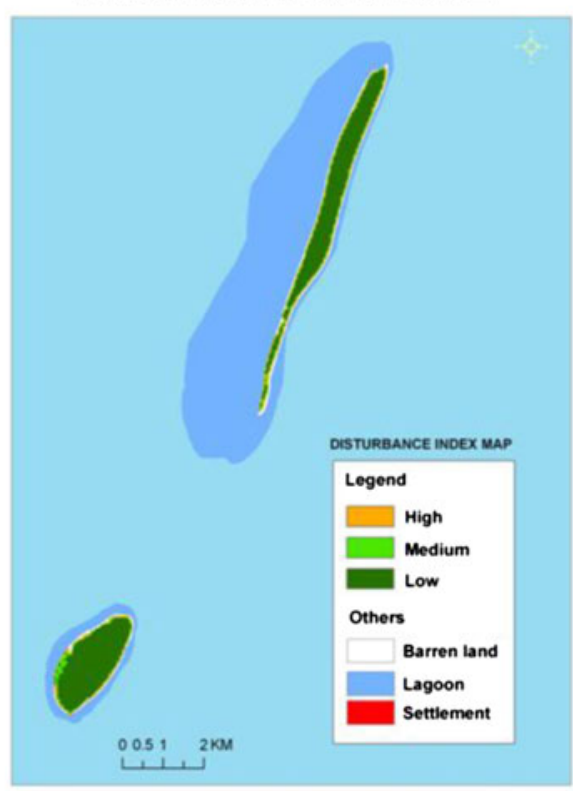

Minicoy island

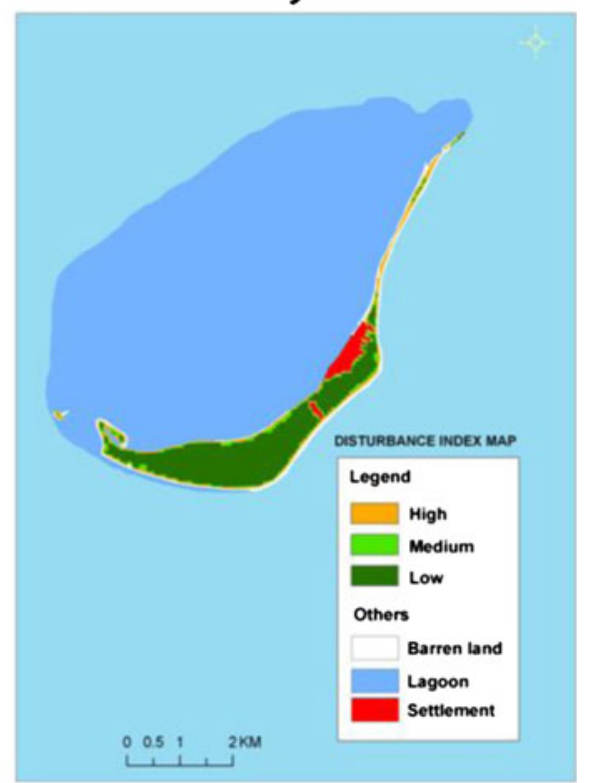

Figure 4. Disturbance index map of major Lakshadweep islands.

sarmentosa, Leucas aspera, Mariscus dubius, Mimosa pudica, Mirabilis jalapa, Phyla nodiflora, Phyllanthus maderaspatana, Phyllanthus urinaria, Portulaca oleracea, Sida acuta, Sida cordata, Spinifex littoreus, Stachytarpheta jamaicensis, Synedrella nodiflora, Tacca leontopetaloides, Tephrosia purpurea, Thecagonum biflorum, Thuarea involuta, Tridax procumbens, Vernonia cinerea and Zaleya decandra) and climbers (Cassytha filiformis, Coccinia grandis, Colubrina asiatica, Gloriosa superba, Ipomoea alba, Merremia turpethum, Passiflora foetida, Teramnus labialis, Tinospora cordifolia and Tylophora indica).

\section{Discussion}

The findings presented here on distribution of remnant natural vegetation is based on very-highresolution IRS P6 LISS IV data and habitat inventory. Spatial information on location and extent of natural vegetation of Lakshadweep islands was analysed through geo-spatial techniques. All the natural vegetation fragments in Lakshadweep landscape contain only one natural littoral vegetation type. But the remnant habitat of littoral vegetation is composed of heterogeneous plant communities. Littoral vegetation occupies major proportion 

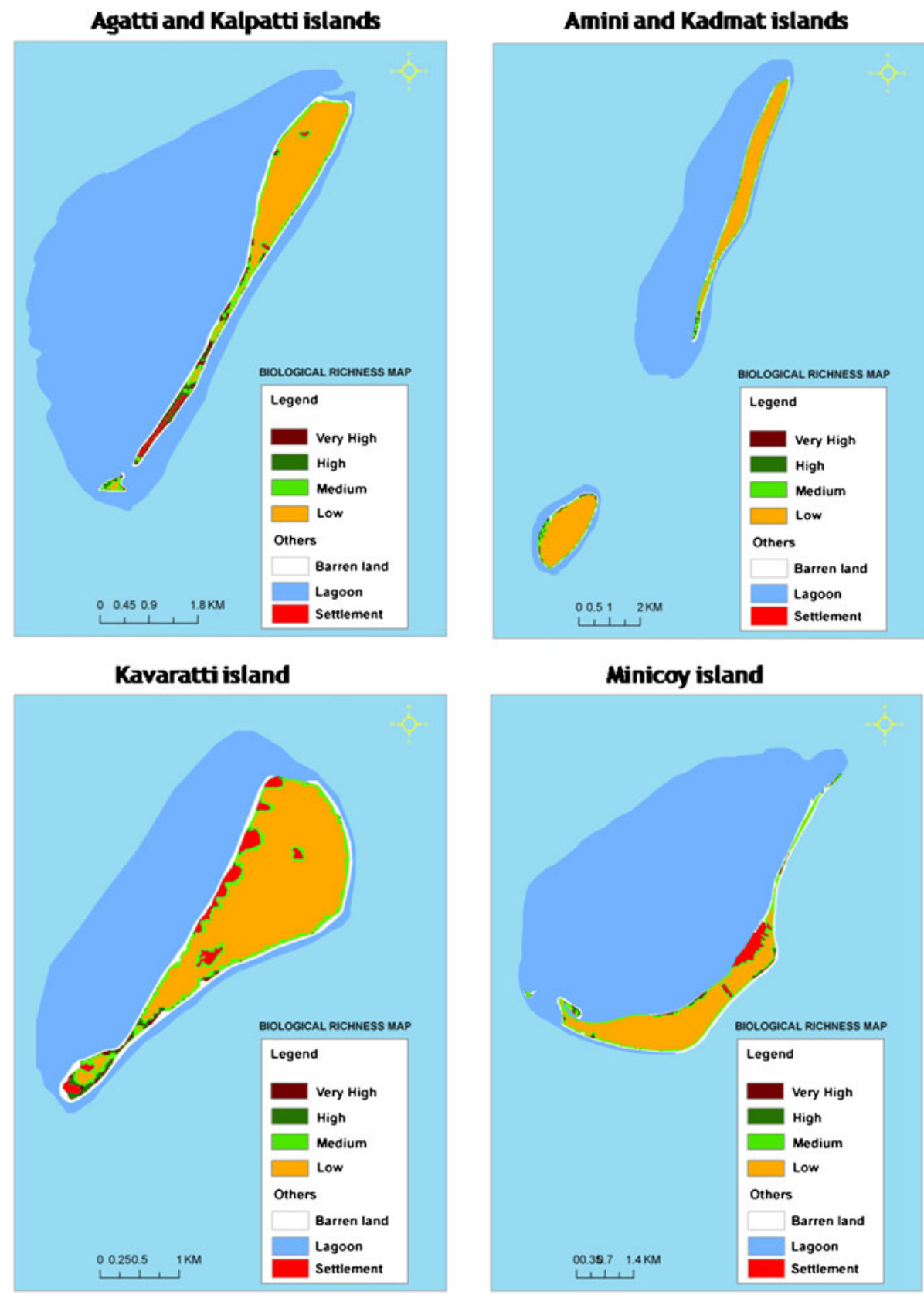

Figure 5. Biological richness map of major Lakshadweep islands.

under uninhabited islands. The low diversity at vegetation type level is due to similar habitat conditions related to altitude, climate, soil and topographical characteristics. Stand density per hectare in Lakshadweep islands is very low as compared to littoral vegetation of Andaman islands and reported as 646 per ha (Prasad et al. 2009).

The area under littoral vegetation varies greatly in different islands and highest coverage was found in Agatti (25.3 ha), followed by Minicoy (16.0), Bangaram (15.1), Thinnakara (15.0), Amini (14.2), Kadmat (10.0), Androth (9.2), Kavaratti (8.2), Kiltan (7.1), Parali I (6.2), Chetlat (3.5),
Kalpatti (1.6), Suheli Cheriyakara (1.5), Bitra (1.5), Cherium (1.2), Kalpeni (0.9) and Parali II (0.7). Littoral vegetation was not observed in Cheria Panniyam Reef, Perumal Par, Pitti, Suheli Valiyakara, Valiya Panniyam Reef and Viringili.

The current landscape scenario of Lakshadweep is characterized by low natural habitat cover $(4.29 \%)$ and a fragment size distribution strongly distorted towards small values $(<5$ ha). The trend is completely different from its counterpart Andaman islands, where only $87.11 \%$ of area was under low fragmentation. The area under high 
fragmentation category in Andaman represents only $0.82 \%$ of total vegetation area (Prasad et al. 2009). The remnant natural vegetation surviving with patches of less 20 ha size indicates severe anthropogenic pressure and necessitates immediate conservation measures. The results show that the low disturbance regimes cover $52.74 \%$ of the total forest area, followed by $28.04 \%$ under medium and $19.22 \%$ under high.

The high disturbance regimes in the littoral vegetation is due to the fact that the presence of isolated small patches, proximity to plantations and settlements. Plantations in Lakshadweep are managed systems and less fragmented. Invasive alien species are suppressing the spread of native plant species and becoming worst threat in many islands. The control of population of Synedrella nodiflora is necessary for the longterm protection of native biodiversity especially in Bangaram, Thinnakara and Parali islands. The spread of Lantana camara in Kavaratti island and Mikania micrantha in Androth island is needed to be checked from further spread.

Study reveals the fact that remnant littoral vegetation areas of Lakshadweep islands are under high biotic pressure. The disturbance index map shows that more than $50 \%$ of the littoral vegetation areas are in the high disturbance regime. So, it can be concluded that there is an urgent need of conservation of biological diversity in situ. When considering total geographical area under protected area coverage, the sand of Pitti island bird sanctuary accounted for $0.01 \%$ of this area. There is no protected area for natural vegetation fragments. The littoral vegetation, although it covers only 137.2 ha $(4.29 \%)$ of the total geographical coverage of the Lakshadweep islands, has representation of $1 \%$ and $2 \%$ of very high and high biological richness area, respectively. About $76 \%$ of plant species in Lakshadweep are economically important (Reddy 2010). It shows the high economic potential of plant resources and dependency of local communities on it. Bio-rich areas identified in the present study can act as base line for creation of future protected areas.

Findings from the present study depicts that littoral vegetation of Lakshadweep islands was affected by severe anthropogenic activities or human-induced changes like invasive species due to clearing. Decreasing patch size may lead to a reduction in the size of populations and to an increased extinction risk of remnant populations. Furthermore, colonization rates may be reduced in isolated patches. This isolation of the forest patches leads to the negative impact on regeneration of plant species and badly affects the survival of species.

\section{Conclusions}

From this study, it has been observed that the remnant natural vegetation of Lakshadweep is under high anthropogenic stress. The spatial database generated in the study will be helpful in initiating conservation measures to protect the threatened habitats and high biodiversity zones. There is an urgent need for declaration of protected areas to conserve this ecologically sensitive and unique ecosystem.

\section{Acknowledgements}

The work has been carried out under the Biodiversity Characterisation Project of Department of Space and Department of Biotechnology, India. The authors are thankful to Dr V Jayaraman, Former Director, NRSC, Dr V K Dadhwal, Director, NRSC, and Dr P S Roy, Director, IIRS, Dehradun, for facilities and encouragement.

\section{References}

Anonymous 1991 Pitti Island, Lakshadweep: An ornithological study; Madras Naturalist Society, Madras.

Behera M D and Roy P S 2010 Assessment and validation of biological richness at landscape level in part of the Himalayas and Indo-Burma hotspots using geospatial modelling approach; J. Indian Soc. Rem. Sens. 38 415-429.

Bierregaard R O Jr, Lovejoy T E, Kapos V, dos Santos A A and Hutchings R W 1992 The biological dynamics of tropical rainforest fragments; BioScience 42 59-866.

Broadbent E N, Asner G P, Keller M, Knappa D E, Oliveiraa P J C, and Silvad J N 2008 Forest fragmentation and edge effects from deforestation and selective logging in the Brazilian Amazon; Biol. Conservat. 141 1745-1757.

Census of India 2011 Ministry of Home Affairs, Government of India.

Champion H G and Seth S K 1968 A Revised Survey of the Forest Types of India; Govt. of India Press, Delhi.

Cottam G and Curtis J T 1956 The use of distance measurement in phytosociological sampling; Ecology 37 451-460.

Curran L M, Caniago I, Paoli G D, Astianti D, Kusneti M, Leighton M, Nirarita C E and Haeruman H 1999 Impact of El Nino and logging on canopy tree recruitment in Borneo; Science 286 2184-2188.

Forman R T T and Godron M 1986 Landscape Ecology; John Wiley and Sons, New York.

http://glcf.umiacs.umd.edu/ Accessed on 21st June 2009.

Innes J L and Koch B 1998 Forest biodiversity and its assessment by remote sensing; Global Ecol. Biogeogr. Lett. 7 397-419.

Jha C S, Goparaju L, Tripathi A, Gharai B, Raghubanshi A S and Singh J S 2005 Forest fragmentation and its impact on species diversity: An analysis using remote sensing and GIS; Biodiversity $\&$ Conservation 14 1681-1698.

Kempf M 1993 A new way to oversee public's forests?; American Forests 99 28-31.

Lehmkuhl J F and Ruggiero L F 1991 Forest fragmentation in the Pacific north west and its potential effect on wildlife. Wildlife and vegetation of unmanaged 
Douglas fir forests; General Technical Report PNW-GTR285, USDA Forest Service, Pacific North West Research Station, Portland, Oregon, pp. 35-46.

Louisa J M J and Antonio D G 2001 Parametric land cover and land use classifications as tools for environmental change detection; Agr. Ecosyst. Environ. 91 89-100.

Ludeke A K, Maggio R C and Reid L M 1990 An analysis of anthropogenic deforestation using logistic regression and GIS; J. Environ. Manag. 31 247-259.

McGarigal K, Cushman S A and Ene E 2012 FRAGSTATS v4: Spatial Pattern Analysis Program for Categorical and Continuous Maps; Computer software program produced by the authors at the University of Massachusetts, Amherst. http://www.umass.edu/landeco/research/ fragstats/fragstats.html.

Murcia C 1995 Edge effects in fragmented forests: Implications for conservation; Trends in Ecol. Evol. 10 58-62.

Prasad P R C, Shringeswara A N, Reddy C S, Nidhi N, Rajan K S, Giriraj A, Murthy M S R, Raza S H and Dutt C B S 2009 Assessment of forest fragmentation and species diversity in North Andaman Islands (India) - A geospatial approach; Int. J. Ecol. Develop. 14(9) $33-46$.
Ramachandra T V, Kamakshi G and Shruthi B V 2004 Bioresource status in Karnataka; Renew. Sustain. Energy Rev. 8(1) 1-47.

Ramesh B R, Menon S and Bawa K S 1997 A vegetation based approach to biodiversity gap analysis in the Agastyamalai region, Western Ghats, India; Ambio 26(8) 529-536.

Reddy C S and Roy P S 2011 Plant diversity of Lakshadweep Islands; National Remote Sensing Centre, Hyderabad \& Bishen Singh Mahendra Pal Singh, Dehra Dun, ISBN: 978-81-211-0784-6.

Reddy C S 2010 Biodiversity characterization at landscape level using satellite remote sensing and GIS in Lakshadweep Islands; Technical Report, National Remote Sensing Centre, Hyderabad.

Rodriguez J P et al. 2010 Establishing IUCN red list criteria for threatened ecosystems; Conservat. Biol. 25 21-29.

Roy P S, Singh S, Dutt C B S, Jeganathan C, Jadav R N, Ravan S A, Diwakar P G, Tomar S, Tiwari A K, Ranganath B K and Hegde V S 1999 Biodiversity characterisation at landscape level using satellite remote sensing and Geographic Information System; DOS-DBT User Manual, Indian Institute of Remote Sensing, Dehra Dun, India. 